\title{
Verse Forms and Metres in Livonian Humanist Poetry: David Hilchen and his Ancient Models
}

\author{
Maria-Kristiina Lotman, Kristi Viiding*
}

\begin{abstract}
The aim of this paper is to give an account of verse forms in David Hilchen's poetry. In the paper the metrical structures and rhythmic regularities in poems gathered from different periods of his creation are studied and the results are compared with the data from ancient Latin authors. Some aspects of the prosodic features in Hilchen's verse are discussed as well. The paper will demonstrate the prosodic and rhythmic variety of the metres used, which resembles the rhythmic preferences of ancient models and early modern verse.
\end{abstract}

Keywords: metre, rhythm, Neo-Latin poetry, hexameter, pentameter, Livonian humanism

\section{Introduction: historical and biographical background}

The earliest signs of Renaissance humanism only appeared in Estonian and Livonian cities just before the Lutheran Reformation of the 1520s and developed slowly during the sixteenth century (for more details, see Viiding 2017). The first peak of Renaissance humanism came as late as the 1580s in Riga during the period of Polish rule (1582-1621/25). This was mainly the result of one person's activities: the Livonian-Polish humanist David Hilchen (also known by the humanist name Heliconius, 1561-1610). It was he who invited the first printer, Claes Mollyn, from Amsterdam to Riga (Buchholtz 1890; Zanders 1998). He also invited the first inspectors of the humanist gymnasium, Johannes Rivius and Salomon Frenzel von Friedenthal, to the city (Buchholtz 1890; Viiding 2014, 2019). Moreover, he organised a small group of humanists around him (Daniel Hermann from Prussia, Georg Ciegler from Tallinn and Salomon Frenzel from Helmstedt; Ramm-Helmsing 1936; Frisch 2015).

As a typical (legal) humanist, Hilchen shaped a clear literary profile for himself. He modelled it on classical examples, especially on Marcus Tullius

\footnotetext{
* Authors' addresses: Maria-Kristiina Lotman, Department of Classical Studies, University of Tartu, Lossi 3, 51003 Tartu, Estonia. E-mail: maria.lotman@ut.ee; Kristi Viiding, Under and Tuglas Literature Centre of the Estonian Academy of Sciences, Roosikrantsi 6, 10119, Tallinn, Estonia. E-mail: kristi.viiding@gmail.com.
} 
Cicero, and on early modern European humanists, particularly those from Germany (Johannes Caselius) and the Low Countries (Justus Lipsius). As a learned lawyer (education in 1580-1582 at the University of Ingolstadt, 15821584 in Tübingen and 1584-1585 in Heidelberg), he became the City Secretary (1585-1589) and Town Jurist (syndicus; 1589-1600) of Riga. In these offices, he composed about twenty-five political, festive, commemorative, and gratulatory speeches in Latin, extending to more than 300 pages. He composed an unfinished historical monograph about the Calendar Riots in Riga (now lost), at least 700 Latin letters to humanists and high officials throughout Europe, and 45 occasional poems. ${ }^{1}$ No one in Livonia had cultivated Latin oratory in such a high style nor used the genre of historical monograph before him. Nor had anybody, in accordance with classical and humanist examples, collected, and systematised into books their own Latin correspondence and prepared it for publication. Evidently, Hilchen did not experiment with epic, comedy, or tragedy, probably because of their lengthiness and lower expected public impact, as there was no theatre in Riga during his time.

After the first politically active half of Hilchen's life, during which he managed to solve a serious dispute between the Riga City Council and the guilds (also known as the Calendar Riots, 1585-1589); take part in more than twenty legations of the City of Riga, Livonia and even of the Polish-Lithuanian Commonwealth; compile various acts and statutes for Riga and Livonia; and, after his ennoblement in 1591, represent both the city of Riga and the Livonian nobility in the Polish Sejm (Landbotenstube), and so on, Hilchen spent the last ten years of his life (1600-1610) in exile, mainly in Zamość, Poland. Officially accused of treason against the city of Riga in 1600, proceedings against him continued through various stages for more than nine years, only being terminated in May 1609 by a decree from the Polish King Sigismund III (Zygmunt III Waza). Yet even after that, Hilchen did not return to Livonia.

One of the first active literary figures from the region, Hilchen completed his basic education at the Riga Cathedral School, and there he learned almost all of his skills in Latin versification before 1579; during his higher education in Germany, he focused instead on rhetoric and law. Thus, his poems are a unique research object for analysing the level of poetics instruction in Livonia in the 1570 s.

Hilchen's Latin poems mostly belong to the genre of occasional poetry. His poetry may be categorised into four periods: juvenilia before 1585, poetry for official events in Riga in 1585-1599, poetry from the crisis period in

1 For the first overview of Hilchen's poetry, see Viiding 2020. 
1599-1602, and court poetry in Poland 1603-1610. Moreover, in his letters he refers to some additional poems he had written, but now they are evidently lost (for example, in 1606 he wrote Jambicum Dunamundense and an epicedium for Justus Lipsius). Although he repeatedly refers in his letters to his ambitious poetic talent during his youth and to his writing in many genres (elegy, odes, heroic epic), this self-assessment cannot be retroactively confirmed or denied because only five poems survive from his last year of university studies. It is possible that the 1941 fire in Riga City Library destroyed the rest of Hilchen's juvenile poetry, but it is equally possible that Hilchen in his old age simply employed the literary topos of the retrospective view on one's poetry talent in the early life. In any case, it is certain that Hilchen never once tried to publish his collected poems, although it would have been easy for him, being the inspector of Riga's printing house 1588-1600 and later a member of Jan Zamoyski's inner circle in Zamość.

In the height of his political activity as a city official in Riga during 15851599, Hilchen only created poetry on an exceptional basis and was rather himself the addressee of the poems. He wrote almost no occasional poems for the traditional circumstances, but rather produced congratulatory poetry for social events: the 1587 election of the king of Poland, the 1589 restitution of Riga's city officials into office, in 1594 for the opening of Academy in Zamość, in 1595 for the high officials of the Polish court and the king, in 1599 for the wedding of Lew Sapieha, member of the revision commission of Livonia. These poems were meant to build up Riga's reputation in the Polish-Lithuanian state, a so-called foreign affairs propaganda. No less important was the promotion of humanist ideals in the Latin inscriptions and portals of the new chancellery of Riga in 1597 and dedicatory poems in the books of Riga's authors, for example, at the beginning of Georg Ciegler's "De incertitudine rerum humanarum" (in all of the numerous editions beginning from the 1598 edition).

During the political crisis and the personal one that accompanied it (15991602), Hilchen wrote and published, under a pseudonym, only one long satire in Latin and two accompanying epigrams that we know about. In the first stage of his trial in Riga (from January 1600 to the death sentence in May 1601), followed by his participation in the Polish-Swedish war in Livonia, there are no known poems by Hilchen until the summer of 1603, despite the mock epigrams that were written against him and his supporters. During these years, poetry became a weapon of warning and combat, and his satire was even part of the judicial charges pressed against him in Riga - Hilchen had allegedly tortured his addressee with it. One of his earlier poems, the Latin epigram-inscription, was even removed from the chancellery building 
of Riga in 1602, although the court decision did not directly order this kind of damnatio memoriae.

During the final period of his life in exile in Poland (1603-1610), Hilchen became a court poet who did not once use the poetic form to express his personal tragedy, but to write traditional occasional poetry in the festive events for Polish dignitaries (six weddings, seven grief poems and three congratulatory poems for the publication of a book). Instead of the short poems in elegiac distich and hexameter particular to the Riga school of humanism, lyrical strophic forms became Hilchen's favoured patterns - Catullus' carmina and Horace's odes, epodic forms and motifs became his exemplar. In one of his first poems written in exile, Hilchen stylised himself as a poet based on the example of Horace's ode 1.1. This aesthetic shift from a public figure and practicing lawyer into a humanist poet was not random but affected by the lyrical ideals of poetry prevalent in the community of the Academy of Zamość; for example, one could be reminded of the Polish Pindar - Szymon Szymonowic (with the humanist name Simonides), who was famous across Europe and who wrote tragedies and epics in addition to lyrics (Winniczuk 1962: 139-148); Adam Burski, a professor of rhetoric who compiled manuscripts about literary figures and rhetoric; or Jan Ursyn-Niedźwiecki, who was counted among the hundred best Polish authors even during the 18th century (for example, Lepri 2019: passim). The long occasional poems of Hilchen's period in exile indicate that he very quickly adopted the style and generic preferences of Polish humanist Neo-Latin poetry.

In this article, we study Hilchen's poetry from the aspect of its versification by separately analysing both its metric structure and, if possible, the rhythmic patterns of different metres. In this way, our first aim is to map the basic versification skills that could have been acquired at the Riga Cathedral School in the 1570s, before the peak of Riga Humanism. Our second aim is to reveal the role of ancient models in the metrical and rhythmical elements of Hilchen's poetry. For comparative material, we use available data from both classical and Neo-Latin metres and data from both literary and epigraphic texts.

\section{David Hilchen's poetic forms: general remarks}

In his Latin poetry, David Hilchen exclusively used quantitative verse metres and forms that followed ancient models. He never experimented with syllabic or accentual systems of versification or rhymed poetry that characterised Medieval Latin verse culture. Regrettably, Hilchen never commented on his 
versification principles in the paratexts of his poetry, letters or in any other of his written works.

All in all, David Hilchen's 45 poems consist of 1297 verses in which he used nine different verse forms, including both stichic and stanzaic forms, in an almost unchanged proportion throughout his creative periods (except for the figurative poem, which is not found in his later works).
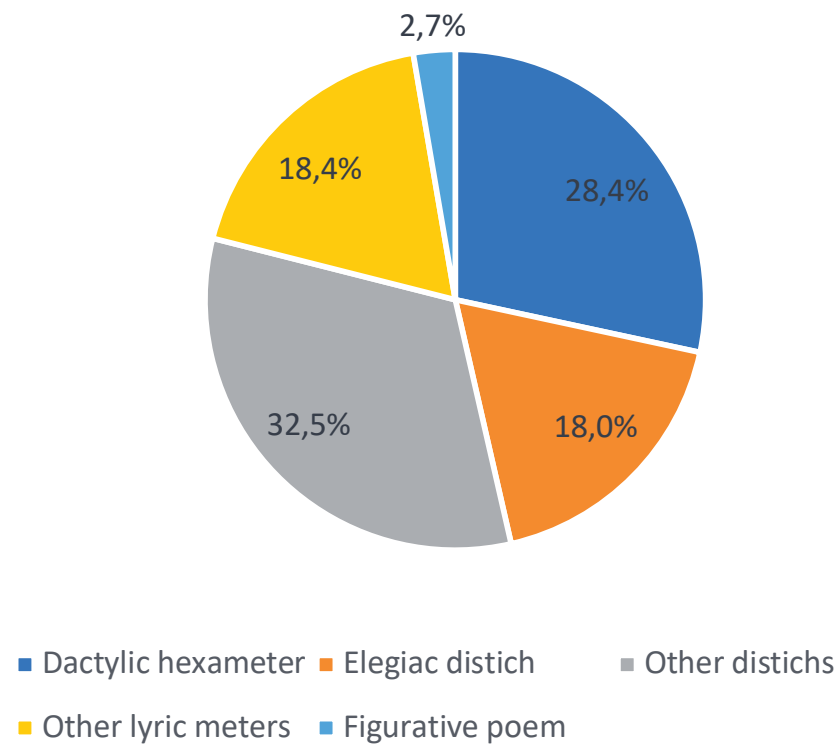

\section{Chart 1. The proportions of different verse forms in Hilchen's poetry}

Among the stichic metres, Hilchen's poetry contains more dactylic hexameters (altogether ca $28 \%$ of his verses), but also hendecasyllables and Asclepiadean verse. Almost all of the stanzaic verse forms in Hilchen's poetry are distichs (all in all, over $50.6 \%$ of all verse forms): the most frequently used is the elegiac distich, then the dactylic hexameter along with the iambic senarius (the so-called Pythiambicum maius), in addition to the Sapphicum maius, which consists of the shorter Aristophanean verse and the longer Sapphic verse (so-called versus Sapphicus maior), the distich composed of the iambic senarius and quaternarius, and finally the so-called Alcmanium, the first verse of which is the dactylic hexameter and the second is the dactylic tetrameter. Considering the background of the European humanist poetry tradition, including turn-of-thecentury Polish Neo-Latin poetry, it is surprising that Hilchen experimented with quatrains only once in a poem written in Sapphic stanzas during his study period in Germany, but not in his exile in Poland. 
In Hilchen's case, alternating usage of stichic and stanzaic verse forms is neither determined strictly by the theme, nor by its genre or the social position of the addressee. A definite connection may only be noted between the stichic verse form and satire, following from the requirements of the genre in ancient Roman literature. ${ }^{2}$ What is probably coincidental is the exclusive usage of the stanzaic form (elegiac distich) in the case of anagrammatic poems. One may also notice a greater variation in metres in his wedding and mourning poems after 1599, whereas poems written for other events are metrically less varied.

\section{The dactylic hexameter in its variety and flexibility}

In Hilchen's poetic corpus, hexameter and its various derivatives in stanzaic forms constitute a sufficiently large sample ( 879 lines, that is, $67,8 \%$ of his total number of verses) for statistical analysis, allowing for comparison of verses both with each other and with the verses of several ancient and humanist Neo-Latin poets. Hilchen's hexameter is rhythmically varied, and his stichic and pythiambic hexameters (a total of 368 and 109 verses, respectively) contain all 16 possible rhythmic forms of hexameter, while there are 15 rhythmic forms (SSSD ${ }^{3}$ does not appear) in his elegiac hexameters (a total of 127 verses). For comparison, we use De Neubourg's statistical data on Virgil's Aeneid (1986: 160), Annika Kuuse's data on a representative of humanist hexameter, Laurentius Ludenius, data from Latin inscriptions gathered from Estonian churches (CEILE4; see also Arukask et al. 2018), and Platnauer's statistics of Latin elegiac authors (Platnauer 1951: 36-37).

2 In Hilchen's poetry of that period, Julius Caesar Scaliger's approach to satire was common, according to which it was not just a genre created by the Roman poets, but it also evolved from the Greek satyr play. Consequently, iamb was also a possible metre for satires (Scaliger lib. 1.12 and 3.97, Scaliger 1994:186-191 and 1995:54-59). Thus, Hilchen justified the usage of iamb in verses 17-18 Accipito haec rursum, quae Panas inter agrestes / Et Satyros lusi hamatis stipatus iambis. ("Accept, in turn, what I composed, armed with hooked iambs, among the feral Pans and satyrs"). The decisive differentiation between the iambic satyr play and formal satire in hexameters took place in Hilchen's lifetime with the treatise De Satyrica Graecorum Poesi et Romanorum Satira by Isaac Casaubon in 1605 (for example, Griffin 1994: 12-14).

3 S - Spondaic foot, D - dactylic foot.

4 CEILE (Corpus Electronicum Inscriptionum Latinarum Estoniae) is the database of the Latin Inscriptions in Estonian Churches from the beginning of the 14th century to 1918. Here, only the inscriptions written in quantitative metrical form are compared, all of which are from the period 1549-1738. For an analytical overview of the metrical inscriptions, compare Arukask 
Table 1. The rhythmic forms of dactylic hexameter: different forms of Hilchen's hexameter compared to ancient and Neo-Latin poets and verse inscriptions

\begin{tabular}{|l|r|r|r|r|r|r|}
\hline $\begin{array}{l}\text { Rhythmic } \\
\text { type }\end{array}$ & $\begin{array}{l}\text { Hilchen } \\
\text { stichic } \\
6 \mathrm{D})\end{array}$ & $\begin{array}{l}\text { Hilchen } \\
\text { (elegiac } \\
6 \mathrm{D})\end{array}$ & $\begin{array}{l}\text { Hilchen } \\
\text { (pythia- } \\
\text { mbic 6D) }\end{array}$ & \multicolumn{1}{l}{$\begin{array}{l}\text { Virgil. } \\
\text { Aen }\end{array}$} & \multicolumn{1}{l}{ Ludenius } & CEILE \\
\hline DDDD & $1.9 \%$ & $4.3 \%$ & $1.8 \%$ & $2.1 \%$ & $3.3 \%$ & $5.2 \%$ \\
\hline DDDS & $9.2 \%$ & $7.7 \%$ & $6.4 \%$ & $6.8 \%$ & $6.3 \%$ & $8.6 \%$ \\
\hline DDSD & $4.6 \%$ & $7.7 \%$ & $5.5 \%$ & $4.7 \%$ & $5.3 \%$ & $6.9 \%$ \\
\hline DDSS & $12.8 \%$ & $5.1 \%$ & $7.3 \%$ & $11.8 \%$ & $8.7 \%$ & $13.8 \%$ \\
\hline DSDD & $3.5 \%$ & $6.0 \%$ & $2.8 \%$ & $3.6 \%$ & $1.3 \%$ & $1.7 \%$ \\
\hline DSDS & $10.1 \%$ & $6.8 \%$ & $9.2 \%$ & $11.2 \%$ & $10.3 \%$ & $6.9 \%$ \\
\hline DSSD & $8.1 \%$ & $14.5 \%$ & $12.8 \%$ & $5.7 \%$ & $8.3 \%$ & $8.6 \%$ \\
\hline DSSS & $16.8 \%$ & $17.1 \%$ & $20.2 \%$ & $14.4 \%$ & $21.0 \%$ & $15.5 \%$ \\
\hline SDDD & $1.9 \%$ & $4.3 \%$ & $1.8 \%$ & $2.0 \%$ & $1.3 \%$ & $0.0 \%$ \\
\hline SDDS & $3.8 \%$ & $4.3 \%$ & $1.8 \%$ & $6.0 \%$ & $4.0 \%$ & $5.2 \%$ \\
\hline SDSD & $4.6 \%$ & $6.0 \%$ & $1.8 \%$ & $3.8 \%$ & $5.7 \%$ & $5.2 \%$ \\
\hline SDSS & $8.4 \%$ & $3.4 \%$ & $5.5 \%$ & $9.6 \%$ & $7 \%$ & $10.3 \%$ \\
\hline SSDD & $1.6 \%$ & $0.9 \%$ & $2.8 \%$ & $2.4 \%$ & $2.3 \%$ & $0.0 \%$ \\
\hline SSDS & $4.1 \%$ & $7.7 \%$ & $6.4 \%$ & $6.0 \%$ & $5.7 \%$ & $6.9 \%$ \\
\hline SSSD & $3.3 \%$ & $4.3 \%$ & $8.3 \%$ & $3.0 \%$ & $2.7 \%$ & $0.0 \%$ \\
\hline SSSS & $4.9 \%$ & $5.1 \%$ & $5.5 \%$ & $7.1 \%$ & $6.3 \%$ & $5.2 \%$ \\
\hline
\end{tabular}

et al. 2018. Latin verse inscriptions from early modern Estonia are a relevant comparative material in Hilchen's case, as five of Hilchen's poems were written as epigraphs for grave monuments or representative buildings and at least two of them (No. 6 and 18) were presented in accordance with their purpose. 
Table 2. The rhythmic forms of dactylic hexameter: different forms of Hilchen's hexameter compared to ancient elegiac poets

\begin{tabular}{|c|c|c|c|c|c|c|}
\hline $\begin{array}{l}\text { Rhythmic } \\
\text { type }\end{array}$ & $\begin{array}{l}\text { Hilchen } \\
\text { (stichic } \\
\text { 6D) }\end{array}$ & $\begin{array}{l}\text { Hilchen } \\
\text { (elegiac } \\
6 \mathrm{D})\end{array}$ & $\begin{array}{l}\text { Hilchen } \\
\text { (pyth- } \\
\text { iambic } \\
6 \mathrm{D})\end{array}$ & Tibullus & Propertius & Ovid \\
\hline DDDD & $1.9 \%$ & $4.3 \%$ & $1.8 \%$ & $1.8 \%$ & $1.3 \%$ & $6.7 \%$ \\
\hline DDDS & $9.2 \%$ & $7.7 \%$ & $6.4 \%$ & $9.2 \%$ & $4.7 \%$ & $9.0 \%$ \\
\hline DDSD & $4.6 \%$ & $7.7 \%$ & $5.5 \%$ & $5.8 \%$ & $6.6 \%$ & $10.0 \%$ \\
\hline DDSS & $12.8 \%$ & $5.1 \%$ & $7.3 \%$ & $14.2 \%$ & $8.6 \%$ & $12.0 \%$ \\
\hline DSDD & $3.5 \%$ & $6.0 \%$ & $2.8 \%$ & $4.2 \%$ & $2.4 \%$ & $9.5 \%$ \\
\hline DSDS & $10.1 \%$ & $6.8 \%$ & $9.2 \%$ & $14.1 \%$ & $11.0 \%$ & $13.8 \%$ \\
\hline DSSD & $8.1 \%$ & $14.5 \%$ & $12.8 \%$ & $6.6 \%$ & $6.0 \%$ & $10.7 \%$ \\
\hline DSSS & $16.8 \%$ & $17.1 \%$ & $20.2 \%$ & $20.0 \%$ & $16.5 \%$ & $13.7 \%$ \\
\hline SDDD & $1.9 \%$ & $4.3 \%$ & $1.8 \%$ & $0.8 \%$ & $2.8 \%$ & $1.6 \%$ \\
\hline SDDS & $3.8 \%$ & $4.3 \%$ & $1.8 \%$ & $4.7 \%$ & $3.0 \%$ & $3.0 \%$ \\
\hline SDSD & $4.6 \%$ & $6.0 \%$ & $1.8 \%$ & $2.1 \%$ & $5.0 \%$ & $2.4 \%$ \\
\hline SDSS & $8.4 \%$ & $3.4 \%$ & $5.5 \%$ & $5.0 \%$ & $12.0 \%$ & $2.1 \%$ \\
\hline SSDD & $1.6 \%$ & $0.9 \%$ & $2.8 \%$ & $0.5 \%$ & $1.3 \%$ & $1.6 \%$ \\
\hline SSDS & $4.1 \%$ & $7.7 \%$ & $6.4 \%$ & $4.2 \%$ & $7.5 \%$ & $2.1 \%$ \\
\hline SSSD & $3.3 \%$ & $4.3 \%$ & $8.3 \%$ & $2.1 \%$ & $3.0 \%$ & $0.5 \%$ \\
\hline SSSS & $4.9 \%$ & $5.1 \%$ & $5.5 \%$ & $4.7 \%$ & $8.6 \%$ & $1.0 \%$ \\
\hline
\end{tabular}

Hilchen's most preferred form of rhythm in both stichic and stanzaic hexameter is DSSS, which is mostly composed of heavy syllables and which in different verse forms makes up about $17 \%$ or more of all the rhythmic variations of his hexameter. In his longer poems, hexameters which correspond with this rhythm scheme often appear adjacently; compare, for example, the following verses $(10.2 .134-136)^{5}$ :

Versificatore indoctum qui fertur alumnum

5 For the texts of all poems and mostly chronological numeration added by the editors, see Hilchen 2021. 
Ex Helicone ortum, quanto est praeclarior hic mons:

Atque ego sum montis quanto observantior hujus.

The incidence rates of the other forms vary somewhat: while in stichic hexameter, the second most frequent rhythm forms are DSDS and DDSS (the first in ca $10 \%$, the second in almost $13 \%$ of the verses), elegiac and pythiambic hexameters contain more DSSD (ca 13-14\% of the cases). DDSS has been avoided almost entirely in the elegiac distich; as for the DSDS variation, it is interestingly the second most frequent form of elegiac hexameter during Hilchen's Livonian period, but it is rare in the elegiac distich of his Polish period. However, it must be noted that its proportion is nearly $10 \%$ in the pythiambic hexameter created during the Polish period.

When we compare the rhythmical data of Hilchen's hexameter with those of the ancient and other humanist authors, we see similar proportions: in Virgil's Aeneid, the most preferred rhythm form is also DSSS, but its incidence is slightly lower (14.39\%; for more details, see De Neubourg 1986: 160). The proportion of DSSD in Hilchen's elegiac and pythiambic hexameter is higher than in other samples studied. Just like in ancient authors (compare Platnauer 1951: 37), the lines beginning with a dactyl outnumber those beginning with a spondee. Similar proportions to those of Hilchen's hexameters from his Polish period are found in the hexametric poetry by Laurentius Ludenius (1592-1654), a professor of rhetoric and poetics at the Academy in Tartu and one of the most prolific Livonian Neo-Latin poets two generations later; in his hexameter, the frequency of this form is up to $21 \%$ (Kuuse 2014). There is no systematic comparative data about works by other early modern Livonian poets.

Relatively large differences in the hexameters of different verse forms appear as well in the ratio of dactylic and spondaic verse feet (compare Table 3 ). While the pythiambic hexameter with its large proportion of spondees (on average, ca 58\% in the scope of the verse line) is reminiscent of the heavy and graceless verse of the early Roman poet Ennius, the elegiac hexameter is more dactylic (the average index of spondees within the verse being 50.6\%), although not as light as Ovid's verse, it is still comparable to the hexameter of the classical elegists. 
Table 3. The distribution of spondaic feet of dactylic hexameter: different forms of Hilchen's hexameter compared to ancient and Neo-Latin poets

\begin{tabular}{|l|l|l|l|l|l|}
\hline & I foot & II foot & III foot & IV foot & Average \\
\hline Hilchen (stichic 6D) & $32.9 \%$ & $52.4 \%$ & $63.9 \%$ & $70.1 \%$ & $54.8 \%$ \\
\hline Hilchen (elegiac 6D) & $30.8 \%$ & $69.2 \%$ & $58.1 \%$ & $56.4 \%$ & $50.6 \%$ \\
\hline Hilchen (pythiambic 6D) & $33.9 \%$ & $67.9 \%$ & $67.0 \%$ & $62.4 \%$ & $57.8 \%$ \\
\hline Ennius & $55.60 \%$ & $56.30 \%$ & $61.40 \%$ & $65 \%$ & $59.60 \%$ \\
\hline Virgil & $39 \%$ & $52.60 \%$ & $59.60 \%$ & $72.50 \%$ & $55.90 \%$ \\
\hline Lucanus & $33.40 \%$ & $54.60 \%$ & $56.80 \%$ & $72.50 \%$ & $54.30 \%$ \\
\hline Ovid & $16.80 \%$ & $52.50 \%$ & $58.80 \%$ & $52.70 \%$ & $45.20 \%$ \\
\hline Propertius & $37.70 \%$ & $51.30 \%$ & $62 \%$ & $71.30 \%$ & $55.60 \%$ \\
\hline Tibullus & $23 \%$ & $55.70 \%$ & $60 \%$ & $75.70 \%$ & $53.60 \%$ \\
\hline Martial & $32 \%$ & $53 \%$ & $64.30 \%$ & $60 \%$ & $52.30 \%$ \\
\hline CEILE & $32.8 \%$ & $44.8 \%$ & $65.5 \%$ & $72.4 \%$ & $53.9 \%$ \\
\hline
\end{tabular}

Studying the distribution of the spondaic verse feet in a verse line also reveals certain differences between the verse forms: stichic hexameter has the socalled rising rhythm (for more details, see Gasparov 1997: 240), where the lowest proportion of spondees is in the first foot and their incidence increases with each successive foot until it culminates in the fourth foot, which stands in sharp contrast with the fifth, dactylic foot. Among ancient poets, this kind of rhythm is characteristic, for example, of Virgil's hexameter. In Hilchen's elegiac hexameters, the proportion of spondees is also lowest in the first foot, but the culmination occurs in the second foot instead, while the frequency of spondees is quite uniform in the third and fourth foot, where their incidence is a bit above the average index. In pythiambic hexameter, the proportion of spondees is lowest in the first foot, then equally high in the second and third foot and a bit lower in the fourth foot. For the last two rhythmic models, with lower rate of spondees in the fourth than in the second foot, no example seems to exist in the surviving heritage of the canonical ancient poets.

Hilchen's preferences for caesurae in his hexameters largely correspond to the proportions of ancient Roman hexameter, although there are small differences: the proportion of masculine caesura has slightly increased (in Hilchen's stichic hexameter, it is $92.1 \%$; in Virgil's Aeneid, $84.5 \%$ ) and the proportion of feminine caesurae has decreased (it is $4.6 \%$ in Hilchen's stichic hexameter and 11.7\% in Virgil's Aeneid; compare Butcher 1940: 130). Worth a mention is 
the proportion of feminine caesura in the fourth foot of Hilchen's pythiambic hexameter, which comprises $8.3 \%$. Compare the data in the following table.

Table 4. The occurrence of caesura in the dactylic hexameter: different forms of Hilchen's hexameter compared to ancient and Neo-Latin poets

\begin{tabular}{|l|l|l|l|l|l|}
\hline & $\begin{array}{l}\text { Hilchen } \\
\text { (stichic } \\
\text { hexameter) }\end{array}$ & $\begin{array}{l}\text { Hilchen } \\
\text { (elegiac } \\
\text { hexameter) }\end{array}$ & $\begin{array}{l}\text { Hilchen } \\
\text { (pyth- } \\
\text { iambic } \\
\text { hexa- } \\
\text { meter) }\end{array}$ & CEILE & $\begin{array}{l}\text { Virgil } \\
\text { Aen. }\end{array}$ \\
\hline Third trochaic & $4.6 \%$ & $4.3 \%$ & $7.3 \%$ & $3.4 \%$ & $11.70 \%$ \\
\hline Penthemimeral & $92.1 \%$ & $92.3 \%$ & $83.5 \%$ & $91.4 \%$ & $84.50 \%$ \\
\hline Hephthemimeral & $1.6 \%$ & $2.6 \%$ & $8.3 \%$ & $5.2 \%$ & $3.80 \%$ \\
\hline Fourth trochaic & $0.0 \%$ & $0.9 \%$ & $0.9 \%$ & $0.0 \%$ & $0.0 \%$ \\
\hline Bucolic diaeresis & $1.4 \%$ & $0.0 \%$ & $0.0 \%$ & $0.0 \%$ & $0.0 \%$ \\
\hline Diaeresis & $0.3 \%$ & $0.0 \%$ & $0.0 \%$ & $0.0 \%$ & $0.0 \%$ \\
\hline
\end{tabular}

Of the five bucolic diaereses in stichic hexameter, two are preceded with a word boundary after the second foot and three with a word boundary after the third foot. In exceptional cases, Hilchen also has hexameters that are divided into two equal parts.

The analysis of the clausulae in Hilchen's hexameter revealed rather large divergences between the different verse forms. The indices for stichic hexameter are very similar to Virgil's Aeneid (for more details, see De Neubourg 1986: 66-67): the most common is the so-called condere gentem type of ending (ca $32 \%$ of verses); for example, compare 10.2.90-92:

Post epulas dabo saepe meas: ossa ossibus addam,

Ossa canes rodant: virtutem rodere cessent.

Nunc primam hanc Satyram ubi, mordax Cerbere, mitto.

In Hilchen's elegiac hexameters, the proportion of this type of clausulae is as high as $47 \%$, resulting in a significant drop in the variability of clausulae: while in his stichic hexameter, 22 different types of clausulae are found, only 14 occur in elegiac hexameter. In pythiambic hexameters, the proportion of this type of verse has dropped to $25.7 \%$, and the number of different variations has thus risen to 23 different forms.

The second most common type of clausulae in Hilchen's stichic hexameters is the clausula in the pattern of conde sepulchro, which occurs in $18.5 \%$ 
of his verses (16.3\% of verses in Virgil's Aeneid have the same clausula). In elegiac hexameter, too, it is the second most frequent type, albeit with a somewhat diminished proportion: $13.7 \%$. In pythiambic hexameter, the second in frequency is the submergere ponto type of clausula, which is present in $15.6 \%$ of verses, while its proportion in Hilchen's other hexametrical forms remains below $10 \%$. A versus graecus type of clausula is used by Hilchen only exceptionally; thus, in this respect, he does not follow the practice of Roman Neoteric poets.

\section{The dactylic pentameter, iamb and hendecasyllable}

The analysis of the rhythm of Hilchen's dactylic pentameter (a total of 117 verses) also brought forth certain divergences in comparison to the ancient pentameter. Namely, similarly to his elegiac hexameter's tendency towards dactylicity, his elegiac pentameters have a noticeably large proportion of completely dactylic verses: $33.3 \%$ (for comparison, Tibullus and Propertius have ca $24 \%$ and Ovid has 30.9\%; for more details, see Platnauer 1951: 37). For example, compare 16.1.24:

Mox cecidit solito more fluentis aquae.

The variation with the spondaic second foot appears in $45.3 \%$ of the cases; for example, compare 9.1.10:

Symbola virtutum: linea nulla vacat.

This index is below that of Ovid's and Tibullus's verse (correspondingly, 52.4\% and 58.6\%), but it surpasses Propertius's $43 \%$. On the other hand, Hilchen has similar proportion of pentameters beginning with two spondees as Ovid (in the pentameter of both poets in ca $8 \%$ of the cases), remaining below Propertius's corresponding index (slightly over 16\%); compare, for example 5.6.8:

Haud fesso DVRAS VNVS adhuc animo 
and 2.2:

Vt libret Reges pondere quisque duos

Therefore, Hilchen's pentameter in its fluidity and display of versification skills is most similar to Ovid's pentameter.

About $10 \%$ of Hilchen's verse corpus is composed in iambic metres (a total of 129 verses). Based on surviving poems, we can conclude that Hilchen started writing iambs only during his Polish period, the opening decade of the 17th century. They never appear in stichic form but always in distichs, mostly with the dactylic hexameter, but in a shorter poem, the iambic trimeter is combined with the iambic dimeter. The sample of 97 verses in six-footed iambs allowed us to make some observations about versification in this metre. Hilchen mostly adheres to the dipodic structure, so it corresponds to the scheme of trimeter, but there are single verses in which the second weak position of the dipody, that is, the double foot, is treated as an anceps, following the rules of the iambic senarius. In such cases, both long and short syllables can appear in this position; compare, for example 12.50:

$\mathrm{Nec}$, quae restingui basiorum millibus

or 17.2.116:

Terrae illius cupido flagitiosior,

in which even two breve positions are filled with a long vowel. Although already in the ancient Roman poetry, the $i$ before $u$ often appears shortened, in most Neo-Latin dictionaries the vowel is indicated as long. For the quantity of the final vowel in cupido in Neo-Latin poetry see, for instance, Berggren 1994: 55, Sjökvist 2007: 98.

Rhythm as well is in accord with the structure of the iambic trimeter: $82.5 \%$ are verses without resolutions, only $2 \%$ of all six-footed iambs contain two resolutions, and there are no verses with three or more resolutions. What is atypical of ancient trimeter, however, is the use of caesurae. While the penthemimeral caesura in the third verse foot is highly dominant in ancient iambic trimeter (for example, in Seneca's verse it accounts for over 90\%), Hilchen's corresponding index is merely $56.7 \%$. A fairly large proportion of 
the verses $(17.5 \%)$ is divided into two equal parts, $10 \%$ of the verses lack the caesura, and in ca $15 \%$ of verses, the caesura has been shifted to the fourth verse foot. Such a distribution of word boundaries has its consequences for the rhythmics of the verse: while the ancient Latin iambic trimeter has a tendency for accents to fall on strong positions in the middle of the verse and on weak positions at the end of the verse line (Lotman 2003: 125; 2006: 299-304), we encounter the following verses in Hilchen's iambic trimeter (16.2.1):

Heus quo pedem trames viator abripit?

In this verse line, the accentual structure in the middle of the verse is in conflict with the verse rhythm (pedem and trames), and since these are disyllabic words in which the stress lies on the first syllable, the verse is divided into two equal parts with the word break after the third verse foot.

We also encountered 100 Phalaecean hendecasyllables, which constitute ca $7,6 \%$ of his verses. In the case of hendecasyllables, he has followed the metric and rhythmic requirements of Catullian version of this meter: although he fills the first positions of the scheme mostly with spondees, in occasional cases he admits syllable sequences corresponding to iambic or trochaic patterns. For example, compare the iambic beginning (13.1.18):

Quid ergo? bene nunc ego ominabor

Or the trochaic beginning (13.1.63):

At quid haec leuioribus Camoenis.

As concerns Hilchen's Sapphic hendecasyllables, they follow the Horatian pattern where the fourth syllable is always long, compare 1.4.2:

Suscipit summam, Duce nunc potenti

There is a regular caesura after the fifth syllable, a constant word accent on the fourth and an almost constant accent on the sixth syllable. 


\section{Some aspects of prosody}

Hilchen has rather accurately followed ancient prosodic principles and has at the same time allowed multiple poetic licences that were acceptable already in ancient Roman poetry. His use of elision is particularly liberal, with significant divergences in different verse metres. His stichic hexameter contains, all in all, 197 elisions, while $42.5 \%$ of the verse lines have at least one elision. This includes hexameters that contain two, three, and, on one occasion, even four elisions; compare (10.2.38):

Inter rura alia elegisti: hinc plurima acerba,

In this aspect, Hilchen's stichic hexameter is comparable to Virgil's rather than Ovid's stichic hexameter with a considerably lower number of elisions (see, for instance, Kent 1923: 90-91).

Hilchen's elegiac hexameter has considerably fewer elisions: all in all, only 26 , while verse lines containing an elision only constitute $17 \%$ of all elegiac hexameters. There are only six verses that contain two elisions and no verses containing more than that. Therefore, the amount of elisions in his elegiac distichs is closer to that of Ovid, Tibullus and Propertius than that of Catullus (Platnauer 1951: 72). His pythiambic hexameter contains a total of 65 elisions, and the proportion of verse lines with an elision is again greater: $48.6 \%$. However, no verse contains more than two elisions, and there are 12 lines in total that have two elisions.

Such remarkably liberal usage of elision may be one of the reasons why Hilchen's poetry was never really valued by his contemporaries. The taste of that era and region appreciated verses without elision, as an evaluation of the master's exam at the University of Frankfurt/Oder from 1584 demonstrates the future professor of theology, Christopher Pelargus, was especially praised for his unelided verses (Arnold 1908: 170). ${ }^{6}$ For example, Hilchen's contemporary poet Sylvester Johannis Phrygius has only 29 verses with elision per 773 verse lines (Sjökvist 2007: 97), which prevailingly occur in his stichic hexameters (14 elisions per 153 stichic hexameters, 15 elisions per 604 elegiac verse lines). On the other hand, Andreas Stobaeus, professor poeseos at Lund

\footnotetext{
6 Later, in the 1590s and 1600s, Pelargus was among Hilchen's correspondents. In 1596-1598, Hilchen tried to invite Pelargus to become the Superintendent of the Livonian Lutheran church, but the invitation process was interrupted because Pelargus did not get permission from the Elector of Brandenburg (Kleeberg 1931: 93-94).
} 
University since 1674, admits elisions more frequently. According to Maria Berggren (Berggren 1994: 54), his poem "Augur Apollo" contains as much as 177 elisions per 858 verses.

On several occasions, the device of synizesis has been used, in which case two syllables are joined into one syllable; for example, compare the following verse, where in order to follow the metrical scheme, the last two syllables of the word 'Bergii' have to be counted as one syllable (3.21):

Caspar, nomen habes BERGII conflata vigerent,

Hilchen often admits certain words as iambically shortened, especially tibi, mihi, ego, and so on. In doing so, he sometimes allows for these words to appear in iambic forms as well; for example, compare 11.54:

Quique fauore tibi iunxit propriamque dicauit

and 13.2.2:

Nunc socia(m) tibi se iungit Constantia virgo.

With similar flexibility, Hilchen uses the opportunity of muta cum liquida; for example, the first syllable of the word patria is sometimes heavy, yet sometimes light. The recurring consonantification of the vowels $i$ and $u$ can be seen as well; compare the consonantified $i$ in the following hexameter (10.2.111):

Sicque tuus tandem admoto cadet ariete crebro

and the simultaneous consonantification of the $u$ and $i$ in pentameter (15.2.2):

Lithuaniae scitum est, legibus innumeris.

Occasionally, mistakes in the syllable quantity occur. For example, Hilchen treats the first syllable of obicit as heavy, while the first syllable of noster is placed in the position of a light syllable. While obicit treated as a closed initial 
syllable is quite well attested in Neo-Latin, noster can perhaps be explained with the licence of considering vowel as open before initial st- (compare with 9.1.4 cited above; see also Platnauer 1951: 62-63).

\section{Discussion and conclusion}

The analysis of versification in David Hilchen's poetry allowed us to draw the following conclusions.

1) The basis for the instruction of versification in the Riga Cathedral School in the 1570s broadly corresponded to the humanist approach to poetics that was predominant in Europe at the time, following from the ancient models. In the Riga school, evidently hexameter and elegiac distich were taught first, whereas the instruction of composing lyrical metres was not common and iambs did not constitute a part of the regular curriculum. On the other hand, the rhythmic variety of the metres used was quite diverse, although this diversity resembles the rhythmic preferences of ancient models and early modern verse, and no distinct local particularities emerged. In accordance with the versification of ancient models (in particular, Ovid's poetry), the rhythmic patterns in different verse forms diverged: the rhythm of the stichic and pythiambic hexameter in Hilchen's poems is noticeably different from that of his elegiac hexameter. As concerns the caesura and clausulae, it seems that Riga students cumulatively imitated the standard patterns, while the rarer forms of ancient caesurae and clausulae became even rarer in their poetry.

2) In the Riga Cathedral School, Hilchen thoroughly mastered the main rules of Latin prosody along with the allowed poetic licences. The instruction in prosodic system was apparently liberal, rather than purist, as is evidenced by abundant prosodic liberties in Hilchen's poetry, including elision, hiatus, iambic shortening and muta cum liquida.

3) Hilchen's ancient models were quite expectedly Virgil, especially in his stichic and dactylic hexameter, as well as Ovid and other Roman elegists, especially in his elegiac hexameter. In the case of pythiambic hexameter, for which Hilchen had only few ancient models (Horace Epod. 14 and 15), his versification is the closest to that of Lucretius.

4) From the perspective of versification, Hilchen's pentameter can be considered the most successful: the fluidity achieved in these verses most resembles the standard that was developed in Ovid's pentameter.

5) Hilchen only began to write iambic verse during his exile in Poland, but he did not attain proficiency. Many of these verses are monotonous and 
without any resolution; in comparison with the ancient models, the most common location of the caesura in the iamb (the penthemimeral break) has shifted, while nearly a fifth of iambs are divided into two equal parts in the middle of the line, and a tenth of his iambs lack a caesura altogether.

6) Similarly, Hilchen began to write hendecasyllables during his exile in Poland, but in these he has managed to imitate the metric and rhythmic patterns of ancient authors more accurately. Since David Hilchen did not publish his collected poems during his lifetime, nor did he take an active role in their dissemination, while he sent his foreign literary correspondents his prosaic texts concerning politics and history, and since there exists no record of him teaching poetics, it would be futile to look for Hilchen's influence in successive works of the Riga humanist authors. However, a study of the poems of Hilchen's contemporary humanist poets in Riga (D. Hermann, B. Plinius and other, less prolific, authors) would be required in order to systematically map the versification skills of the Riga poets. ${ }^{7}$

\section{References}

Arnold, Karl Franklin 1908. Christoph Pelargus aus Schweidnitz in seinen Beziehungen zu Schlesien. In: Zeitschrift des Vereins für Geschichte Schlesiens 42. Breslau: Wohlfahrt, 151-187.

Arukask, Anni; Kriisa, Kaidi; Lotman, Maria-Kristiina; Truusalu, Tuuli Triin; Uudevald, Martin; Viiding, Kristi 2018. Verse texts in the Latin inscriptions of Estonian ecclesiastical space: Meter and prosody. In: Studia Metrica et Poetica 5(1), 80-104. https://doi.org/10.12697/smp.2018.5.1.04

Berggren, Maria 1994. Andreas Stobaeus two panegyrics in verse. Edited with introduction, translation and commentary. Uppsala: Almquist \& Wiksell.

Buchholtz, Arend 1890. Geschichte der Buchdruckerkunst in Riga 1588-1888: Festschrift der Buchdrucker Rigas zur Erinnerung an die vor 399 Jahren erfolgte Einführung der Buchdruckerkunst in Riga. Riga: Müller.

Butcher, William Guy Deane 1914. The Caesura in Virgil, and Its Bearing on the Authenticity of the Pseudo-Vergiliana. In: The Classical Quarterly 8(2), 123-131. https://doi.org/10.1017/S0009838800019753

\footnotetext{
7 We are grateful to the anonymous reviewers for their extremely useful comments and suggestions that helped us to improve our study.
} 
De Neubourg Leo 1986. La base métrique de la localisation des mots dans l'examétre latin. (Verhandelingen van de Koninklijke Academie voor Wetenschappen, Letteren en Schone Kunsten van Belgie, Kl. der Letteren, Jaargang 48, Nr. 119.) Brussels: AWLSK, Paleis der Academiën.

Frisch, Magnus 2015. Daniel Hermann - a well-travelled Prussian humanist and his poetic work in Riga. In: Letonica. Humanitāro Zinātņu Žurnāls 30, 44-57.

Gasparov, Mikhail L. 1997. Russkij geksametr i drugie natsional'nye formy geksametra. In Gasparov, Mikhail L. Izbrannye trudy. Tom 3. O stikhe. Moscow: Jazyki russkoj kul'tury, 234-258.

Griffin, Dustin 1994. Satire: A Critical Reintroduction. Lexington: The University Press of Kentucky.

Hilchen, David 2021. Sub velis poeticis. Lateinische Gedichte. Herausgegeben, übersetzt und kommentiert von Kristi Viiding und Martin Klöker. Mit einem Vorwort von Kristi Viiding und Maria-Kristiina Lotman (Baltische literarische Kultur 4). Münster: LIT.

Kent, Roland G. 1923. Likes and Dislikes in Elision, and the Vergilian Appendix. In: Transactions and Proceedings of the American Philological Association 54, 86-97. https://doi.org/10.2307/282844

Kleeberg, Gerhard 1931. Die polnische Gegenreformation in Livland. Leipzig: Heinsius.

Korzeniewski, Dietmar 1989. Griechische Metrik. Darmstadt: Wissenschaftliche Buchgesellschaft.

Kuuse, Annika 2014. The syllabic structure of the hexameters of academic occasional poetry in Tartu in the 17th century. Unpublished conference paper.

Lepri, Valentina 2019. Knowledge Transfer and the Early Modern University: Statecraft and Philosophy at the Akademia Zamojska (1595-1627). Leiden, Boston: Brill.

Lotman, Maria-Kristiina 2003. Jambiline trimeeter: värsisüsteemid, meetrum, rütm, semantika. Tartu: Tartu Ülikooli Kirjastus.

Lotman, Maria-Kristiina 2006. Ancient iambic trimeter: a disbalanced harmony. In: Dresher, B. Elan; Friedberg, Nila (eds), Formal approaches to poetry: recent developments in metrics (Phonology and phonetics; 11). Berlin; New York: Mouton de Gruyter, 287-308.

Platnauer, Maurice 1951. Latin Elegiac Verse: A Study of the Metrical Usages of Tibullus, Propertius \& Ovid. Cambridge: Cambridge University Press. 
Ramm-Helmsing, Herta von 1936. David Hilchen 1561-1610. Syndikus der Stadt Riga. Posen: Historische Gesellschaft für Posen.

Scaliger, Julius Caesar 1994-1995. Poetices libri septem. Sieben Bücher über die Dichtkunst. Vol.I and III (edited, translated, commented and introduced by Luc Deitz). Stuttgart: Bad Cannstatt.

Sjökvist, Peter 2007. The Early Latin Poetry of Sylvester Johannis Phrygius. Edited, with introduction, translation and commentary by Peter Sjökvist. Uppsala: Uppsala universitet.

Viiding, Kristi 2014. Salomon Frenzel von Friedenthal - Endstation eines Humanistenschicksals. In: Ludwig Braun (ed.), Album alumnorum. Gualthero Ludwig: Septimum decimum lustrum emenso, dedicatum. Würzburg: Königshausen \& Neumann, 209-227.

Viiding, Kristi 2017. Das Verhältnis der Reformation und des Humanismus in Estund Livland im 16. Jahrhundert. In: Assel, Heinrich; Steiger, Johann Anselm; Walter, Axel E. (eds.), Kulturwirkungen der Reformation in den Metropolen des Ostseeraums. Berlin: W. de Gruyter, 843-854.

Viiding, Kristi 2019. Salomon Frenzels schwere Mission in Riga. In: Neulateinisches Jahrbuch. Journal of Neo-Latin Language and Literature 21, 329-346.

Viiding, Kristi 2020. Der Humanist in der Krise. Zur Rolle der Poesie im Leben des Rigaer Humanisten David Hilchen. In: Schaffenrath, Florian; Hernández, María Teresa Santamaría (eds.), Acta Conventus Neolatini Albasitensis. Proceedings of the Seventeenth International Congress of Neo-Latin Studies (Albacete 2018). Leiden: Brill, 663-674.

Winniczuk, Lidia 1962. Die lateinische Dichtung des Simon Simonides (1558-1629). In: Renaissance und Humanismus in Mittel- und Osteuropa. Eine Sammlung von Materialien besorgt von Johannes Irmscher. Bd. 2. Berlin: Akademie-Verlag, 139-148.

Zanders, Ojārs 1998. Nicolaus Mollyn, der erste Rigaer Drucker. Sein Schaffen in Riga von 1588 bis 1625. In: Garber, Klaus (ed.), Stadt und Literatur im deutschen Sprachraum der frühen Neuzeit, II. Tübingen: Niemeyer, 786-800.

https://doi.org/10.1515/9783110239553.786 